\title{
THE IMPACT OF MACROECONOMIC INDICATORS ON INDIAN STOCK PRICES: AN EMPIRICAL ANALYSIS
}

\author{
GIRI A. K.
}

Department of Economics and Finance, Birla Institute of Technology and Science (BITS), India

\section{JOSHI Pooja}

Department of Economics and Finance, Birla Institute of Technology and Science

(BITS), India

\begin{abstract}
:
The purpose of the present study is to examine the long run and the short run relationship between stock price and a set of macroeconomic variables for Indian economy using annual data from 1979 to 2014. The long run relationship is examined by implementing the ARDL bounds testing approach to co-integration. VECM method is used to test the short and long run causality and variance decomposition is used to predict long run exogenous shocks of the variables. The results confirm a long run relationship among the variables. Evidence suggests that Economic growth, inflation and exchange rate influence stock prices positively. However, crude oil price influences the stock price negatively. This implies that the increase in oil price induces inflationary expectation in the mind of investors and hence stock prices are adversely affected. The VECM result indicates that short run and long run unidirectional causality running from economic growth and FDI to stock prices in India. The result of the variance decomposition shows that stock market development in India is mostly explained by its own shocks. The Government can take steps to control the crude oil price in India and Investors' confidence has to be gained by boosting the economic growth of the economy through appropriate policy tools.
\end{abstract}

Key words: BSE index, Economic Growth, crude oil price, ARDL, VECM

\section{Introduction}

The claim that macroeconomic variables affect stock market is a wellestablished theory in the literature and has been an area of intense interest among academics, investors and stock market regulators since 1980s. In the past two decades, there has been growing efforts made by researchers to empirically estimate this relation (Chen et al. (1986), Taylor (1992), Fama $(1990,1991)$, Pearce \& Roley 
(1988)) modeled the relation between asset prices and real economic activities in terms of production rates, productivity, growth rate of gross national product, unemployment, yield spread, interest rates, inflation, dividend yields, and so forth. More recently, developed and emerging economies are given an increasing amount of attention to study the relationship between the stock market and fundamental macroeconomic factors (Mukherjee and Naka (1995), Maysami et al. (2004), Ratanapakorn and Sharma (2007), Rahman et al. (2009)). The studies confirm that there exist a relationship between the stock market and macroeconomic factors, but the sign and causal relationship might not hold equal for all- the studies, may be because of using different approaches. However, the role of macroeconomic variables in stock markets is relatively less studied for developing country like India.

Since 1991, when the government of India has adopted the liberalization and globalization policies, Indian stock market has undergone tremendous changes. As a result, the stock market becomes an important aspect of the Indian economy. Moreover, the stock market also plays an important role in financial development and economic growth of the economy, as it is one of the major sources of raising resources for Indian corporate. In fact, Indian stock market is one of the emerging markets in the world. The smoothing development process in Indian stock markets is spectacular. From 3,739.69 points on March 31 $1^{\text {st }}, 1999$, Bombay Stock Exchange (BSE) Sensitivity Index (SENSEX) had reached to 21,000 level points in January, 2008. But this impact doesn't last long as it was affected by the global financial crisis of 2008-09 and emerging euro-crisis. Now SENSEX is hovering around 25,500 points. In the context of this effect in Indian Stock Market, the critical question is whether the decades old development or recent degradation in the markets are in any way influenced by the domestic and international macroeconomic fundamentals.

Studies on Indian stock market behavior have also been conducted in recent years. Agrawalla (2008) stated that a positive change in the stock market cannot be considered as a leading indicator for the revival of the Indian economy. Whereas, Shah and Thomas (1997) concluded that changes in stock prices reflect the real economy. Similar results were found in Kanakaraj et al. (2008). There are several other studies regarding the relationship between share market returns and the macroeconomic variables and all studies provide a different conclusion based on the different data sets and methodologies used. The result of this study help in exploring whether the movement of the stock market indices is the result of the change in fundamental macroeconomic variables or it is one of the causes of change in those variables of the Indian economy. Hence, an attempt is made in the present paper to link both these developments. However, unlike the conventional studies, in this paper, we employ the Auto Regressive Distributed Lag (ARDL) approach to co-integrate to examine the longrun stability between the macroeconomic variables and Indian stock prices. The study also uses VECM based granger causality to check the direction of causal relationships between variables. Variance Decomposition (VDC) is used to explore the degree of exogeneity of the variables involved in this study. For the purpose of analysis annual data starting from the year 1979 to 2014 are used. 
The rest of the paper is organized as follows: Section 2 presents the review of empirical literature on the relationship between selected macroeconomic variables and stock market capitalization. Section 3 outlines the data issues and econometric methodology used in the study; section 4 analyses the empirical results of the study, and section 5 presents the concluding remarks.

\section{Literature Review}

The relationship between macroeconomic variables and the stock market is an important area of research addressed by many researchers nationally and internationally.

Gjrde and Saettem (1999) examined the causal relation between stock returns and macroeconomic variables in Norway. Results showed that a positive link exists between oil price, real activity and stock returns. A study by Flannery and Protopapadakis (2002) concluded that two popular measures of aggregate economic activity (real gross national product and industrial production) were not related to stock returns. Mokerjee and Qiao (1997) investigated that stock prices co-integrated with both measures of the money supply (M1 and M2) and aggregate foreign exchange reserves. Ibrahim and Aziz (2003) investigated the relationship between stock prices and IPI, money supply, CPI and exchange rate in Malaysia. Stock prices were found to share a positive long-run relationship with IPI and CPI.

Cheng and $\mathrm{Ng}$ (1998) and Sharma (2002) investigated the long-run relationship between the fundamental macroeconomic variables and stock prices and the results suggest that in the long run, stock prices will be positively related to growth and output. Ben et. Al. (2007) and Charles (2008) found that saving rate, banking sector development, financial intermediary, stock market liquidity and the stabilization variable are the important determinants of stock market development. Uddin and Alam $(2007,2009)$ found that Interest Rate has a significant negative relationship with Share Price. Coleman and Tettey (2008) studied the impact of macroeconomic indicators on the Ghana Stock Exchange (GSE) and concluded that lending rates from deposit money banks and inflation have an adverse impact on stock market performance contradict to the findings of Adam and Tweneboah (2008). Rahman et al. (2009) showed that monetary policy variables have considerable long-term effects on the Malaysian stock exchange. Pal and Mittal (2011) found that changes in Indian stock markets are affected by change in few selected macroeconomic variables. Ray (2012) draws that there is unidirectional causality exist between stock price and inflation, FDI, GDP, and exchange rate.

Mukherjee and Naka (1995); Naik and Padhi (2012); Hussin et. Al. (2012) and Makan et al. (2012) used the VECM to model the relationship between the stock prices and macroeconomic variables and, hence, a long-run equilibrium relationship exists between them. Hsing and Budden (2012) applied the exponential GARCH model and found that the Argentine stock market index is positively associated with real GDP, the 
ratio of M2 money supply to GDP, the peso/USD exchange rate and the U.S. stock market index. Bekhet and Matar (2013) found the existence of a long-term equilibrium relationship between the Stock Price Index and the macroeconomic variables. Mazuruse (2014) used canonical Correlation Analysis (CCA) found that maximization of stock returns at the ZSE is mostly influenced by the changes in CPI, money supply, exchange rate and treasury bills. Rafay et al. (2014) found a unidirectional relationship between exchange rate and KSE 100 index. Bhargava (2014) found that interest rates are significant predictors of stock price movements. Pradhan (2014) used panel VAR and found the presence of both unidirectional and bidirectional causality links between macroeconomic variables and stock market.

\section{Methodology and Data Description}

\subsection{Model Specification and Data}

The following general specification has been used in this study to empirically examine the effect of economic growth and other fundamental macroeconomic factors on the stock market.

$$
\text { LESF }_{t}=\alpha_{0}+\alpha_{1} \text { LGDP }_{\mathrm{t}}+\alpha_{2} L C O_{\mathrm{t}}+\alpha_{8} \mathrm{LCPI}_{\mathrm{t}}+\alpha_{4} \mathrm{LEXX_{ \textrm {t } }}+\alpha_{2} \mathrm{LFDI}_{\mathrm{t}}+\alpha_{6} \mathrm{LRIR}_{\mathrm{t}}+\varepsilon_{\mathrm{t}}
$$

Where LBSE = Sensitivity index of Bombay Stock Exchange (Sensex), LGDP= Real Gross Domestic Product, LCO= international crude oil price, LCPI = Consumer Price Index, LEX= Real Effective Exchange Rate, LFDI= Foreign Direct Investment, and $\mathrm{LRIR}=$ Real Interest rate variable, in the general model specification above. All the variables are taken in their natural logarithm.

Stock market development is usually measured by stock market size, liquidity, volatility, concentration and integration with world capital markets. The stock market index is Sensex (or BSE 30), an index of 30 well established and financially sound companies listed on the BSE. The Sensex is intended to represent an entire stock market and thus track the market changes over time. Therefore, in this study, we have taken the sensitivity index of BSE (Sensex) to track the changes in the market over time (with respect to other macroeconomic variables) represented by LBSE (Naik and Padhi, 2012).

GDP represents economic growth and economic growth is the increase in the inflation-adjusted market value of the goods and services produced by an economy over time. It is conventionally measured as the percent rate of increase in real gross domestic product, or real GDP. Gross domestic product (GDP) is regarded as one of the important determinants of stock market performance and has often been used to measure the growth of real economic activity. Growth is usually calculated in real terms, i.e., inflation-adjusted terms to eliminate the distorting effect of inflation on the 
price of goods produced. King and Levine (1993) were the first to address the relationship between financial development and economic growth using a crosscountry regression context. This result is quite robust across countries and periods (Levine et al., 2000; Beck and Levine, 2004; Sahay et al., 2015). The relationship between stock price and economic growth has also been studied by Fama (1990, 1991), Levine (1991), Levin and Zervos (1996). The study expects a strong positive correlation between stock prices and real activity.

The Real Effective Exchange Rate (REER) is the weighted average of a country's currency relative to an index or basket of other major currencies adjusted for the effects of inflation. Or, conceptually, the REER, defined as a weighted average of nominal exchange rates adjusted for relative price differential between the domestic and foreign countries, relates to the purchasing power parity (PPP) hypothesis (RBI Bulletin). Here, for the purpose of the study REER based on 36 currency indices has been taken to know that over a trend how the change in the exchange rate has an impact on stock prices. According to Fama (1981), the exchange rate is a double edge weapon. A devaluation of domestic currency increase export, hence improve the cash flow and divide payoffs for firms that rely on exports. On the other hand, depreciation of home currency makes imports costlier and decreases the cash flow and hence affects the industries which depend on imports. The relationship between exchange rate and stock prices is positive (Gay, 2008; Lijuan and Ye, 2010) whereas others found it negative (Abugri, 2008). Hence the relationship between stock prices and exchange rate is an empirical one.

Changes in the international crude oil prices are often considered an important factor for understanding fluctuations in stock prices. For the purpose of study, international crude oil prices per 1000 barrels has been used. On theoretical grounds, oil price shocks affect stock market prices or returns through their effect on expected earnings (Jones and Kaul, 1996), the higher shipping cost can reduce company's profit and the dividends it pays to shareholders. As a result, its stock price may drop. Hence, according to some studies crude oil prices are negatively related to stock prices (Miller and Ratti, 2009; Basher et al., 2012) whereas some others found a positive relationship (Sahu et al., 2014).

FDI is increasingly being recognized as a major source of economic development. The general belief is that FDI facilitates the transfer of technology, organizational and managerial practices, skills and access to international market. Therefore, to access the impact of foreign capital inflows, we have taken Foreign Direct Investment (FDI). According to some studies FDI has a negative and significant impact on stock market capitalization (See: Raza, 2012) while some found that FDI has a positive and significant impact on stock market (Adam and Tweneboah, 2008; Raza et al., 2012).

Inflation represents one of the major threats to stock investors. When the inflation rates start to rise, investors get very nervous anticipating the potentially negative consequences and therefore because of lack of confidence among investors, they resist to invest in the stock market which leads to a decline in stock prices. 
Therefore, researcher found a negative relationship between inflation and stock prices (Fama, 1981). On the other hand, Fisher (1911) hypothesized that shares, are hedged against inflation in the sense that an increase in expected inflation leads to a proportional change in nominal share returns, some studies propounded that positive relationship is also possible between inflation and stock prices as unexpected inflation raises the firms' equity value if they are net debtors (Kessel, 1956; loannidis et al., 2004).

Several studies have established the fact that the interest rate and stock prices are closely related. According to Nishant and Shaheen (2004), increase in interest rate causes a substitution effect and decreases the demand for stocks. Some researchers found this negative relationship between interest rate and stock prices (Alam and Uddin, 2009; Hsing 2004) and this is generally assumed that negative relationship is partly based on the view that a decrease in interest rates leads to lower borrowing costs for firms, higher future profits, and thus higher stock prices.

The Study empirically estimated the effect of fundamental macroeconomic variables on stock prices with the help of above described methodology for India. The study uses annual data covering the period from 1979 to 2014 . The data has been taken and compiled from Handbook of Statistics on Indian economy, RBI; Economic Survey, Government of India; World Bank database; Official website of SEBI and RBI.

\subsection{Co-integration with ARDL}

To empirically analyze the long run relationship and dynamic interaction of Stock Market Index with macroeconomic variables, the above model has been estimated by the Auto Regressive Distributed Lag (ARDL) co-integration procedure developed by Pesaran et al. (2001). The procedure is adopted for four reasons. Firstly, the bounds testing is simple as opposed to other multivariate co-integration technique such as Johansen \& Juselius (1990), it allows co-integrating relationship to be estimated by OLS once the lag order is selected. Secondly, the bound test procedure does not require the pre testing of the variables included in the model for unit root unlike other techniques such as Engle and Granger (1987) and Johansen \& Juselius (1992). These approaches require that all the variables to be integrated of the same order (I(1)). Otherwise the predictive power will be lost (Kim et al., 2004; Perron, 1989, 1997). However ARDL technique is applicable irrespective of whether regressor in the model is $I(0)$ or I (1). The procedure will, however collapse in the presence of $I(2)$ series. Thirdly, the test is relatively more efficient in small sample data sizes as is the case of this study. Fourth the error correction method integrates the short run dynamics with long run equilibrium without losing long run information. The unrestricted error correction model (UECM) of ARDL model is used to examine the long run \& the short run relationship take the following form. 


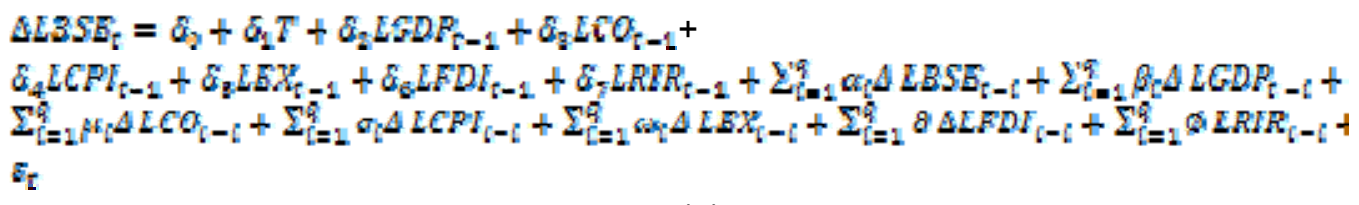

Where the series is as defined earlier and $T$ is time trend and $L$ implies that the variables have been transformed in natural logs. The first part of the equation (2) with $\delta_{2}, \delta_{3}, \delta_{4}, \delta_{2}, \delta_{6}$ and $\delta_{7}$ refer to the long run coefficients and the second part with $\alpha, \beta$, $\mu, \sigma, \omega, \sigma$ and $\forall$ refers to the short run coefficients. The null hypothesis of no cointegration $\mathscr{G}_{\Omega}: \delta_{1}=\delta_{2}=\delta_{9}=\delta_{4}=\delta_{2}=\delta_{6}=\delta_{5}=0$ and the alternative hypothesis $H_{1}: \delta_{1}=\delta_{2} \neq \delta_{3} \neq \delta_{2} \neq \varepsilon_{2} \neq \delta_{0} \neq \delta_{7} \neq 0$ implies co-integration among the series (equation 2).

\subsection{ARDL Bounds Testing Approach}

The first step in the ARDL test is to estimate the equation (2) by OLS in order to test for the existence of a long run relationship among variables by conducting an Ftest for the joint significance of the coefficients of the lagged levels of variables i.e. $\mathrm{H}_{0}$ (Null hypothesis) as against $\mathrm{H}_{1}$ (Alternative hypothesis) as stated earlier.

In the second step, once the co-integration is established the conditional ARDL long run model for $L B S E_{\mathrm{r}}$ can be estimated as:

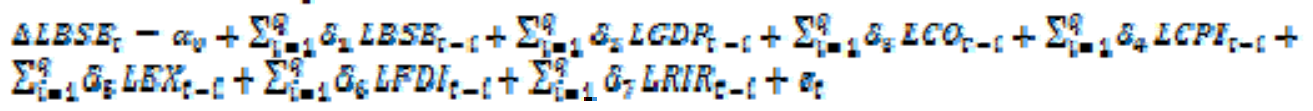

All the variables used are defined in section 3.1

The third and final step, we obtain the short run dynamic parameters by estimating an error correction model with the long run estimates. This is specified as below:

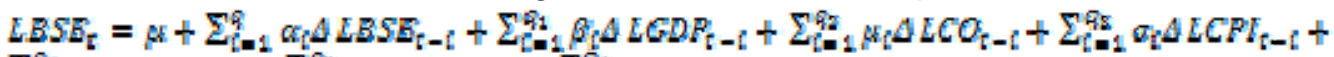

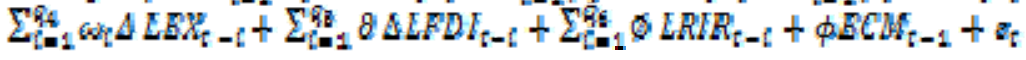

Where $\alpha, \beta, \mu, \sigma, \omega, \delta$ and $\varphi$ are short run dynamic coefficient to equilibrium and $\phi$ is the speed adjustment coefficient.

\subsection{VECM based Granger Causality Test}

The direction of causality between stock prices and macroeconomic indicators is investigated by applying Vector Error Correction Model (VECM) granger causality approach after confirming the presence of co-integrating relationship among the above mentioned variables. Granger (1969) argued that VECM is more appropriate to examine the causality between the series at I(1). VECM is restricted form of 
unrestricted VAR and restriction is levied on the presence of the long-run relationship between the series. The system of error correction model (ECM) uses all the series endogenously. This system allows the predicted values to explain itself both by its own lags and lags of forcing variables as well as the lags of the error correction term and by residual term. The VECM equation is modeled as follows:

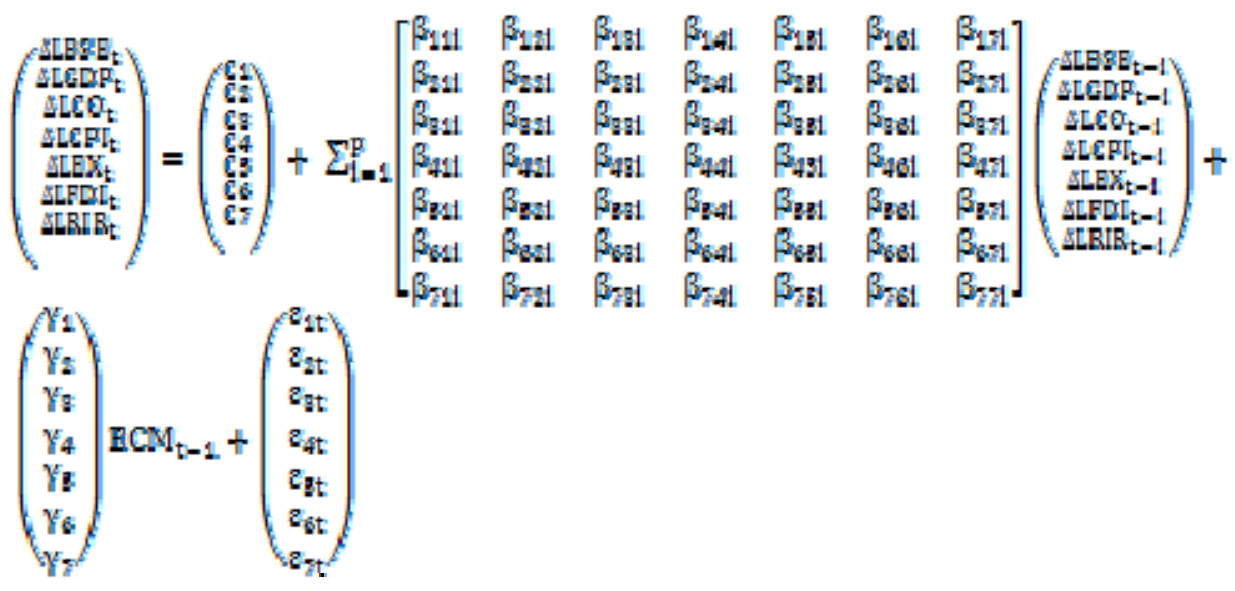

The C's, $\beta$ 's and $\gamma$ 's are the parameters to be estimated. $\mathrm{ECM}_{\mathrm{t}-1}$ represents the one period lagged error-term derived from the co-integration vector and the $\varepsilon$ 's are serially independent with mean zero and finite covariance matrix. From the Equation (5) given the use of a VAR structure, all variables are treated as endogenous variables. The $\mathrm{F}$ test is applied here to examine the direction of any causal relationship between the variables. The LGDP variable does not Granger cause LBSE in the short run, if and only if all the coefficients of $\beta 12$ i's are not significantly different from zero in Equation (5). There are referred to as the short-run Granger causality test. The coefficients on the ECM represent how fast deviations from the long-run equilibrium are eliminated. Another channel of causality can be studied by testing the significance of ECM's. This test is referred to as the long run causality test.

\section{Estimation results}

\subsection{Stationarity test and Lag length selection before co-integration}

Before we conduct tests for co-integration, we have to make sure that the variables under consideration are not integrated at an order higher than one. Thus, to test the integration properties of the series, we have used $\mathrm{Ng}$-Perron unit root test. The results of the stationarity tests are presented in Table 1 . The results show that all the variables used in this study are integrated of order one i.e. difference stationary I(1). Therefore the study uses autoregressive distributed lag (ARDL) approach to cointegration. In addition, it is also important to ascertain that the optimal lag order of the 
model is chosen appropriately so that the error terms of the equations are not serially correlated. Consequently, the lag order should be high enough so that the conditional ECM is not subject to over parameterization problems (Narayan, 2005; Pesaran 2001). The results of these tests are presented in Table 2. The results of Table 2 suggest that the optimal lag length is one based on both LR, FPE, SIC and HQ.

Table 1: Unit root test: Ng-Perron Test

\begin{tabular}{|c|c|c|c|c|c|}
\hline \multirow[t]{2}{*}{ Variables } & \multicolumn{4}{|c|}{ With constant and trend } & \multirow{2}{*}{$\begin{array}{c}\text { Stationarity } \\
\text { Status }\end{array}$} \\
\hline & Mza & MZt & MSB & MPT & \\
\hline LBSE & 0.624 & 0.461 & 0.739 & 38.204 & I (1) \\
\hline$\Delta$ LBSE & -16.386 & -2.861 & 0.174 & 1.499 & \\
\hline LGDP & 2.210 & 2.215 & 1.002 & 86.222 & $I(1)$ \\
\hline$\Delta$ LGDP & -15.289 & -2.717 & 0.177 & 1.780 & \\
\hline LCO & -2.858 & -1.172 & 0.409 & 8.501 & I (1) \\
\hline$\Delta \mathrm{LCO}$ & -16.390 & -2.820 & 0.172 & 1.651 & \\
\hline LCPI & -12.87 & -2.492 & 0.193 & 2.073 & I (1) \\
\hline$\Delta \mathrm{LCPI}$ & -16.161 & -2.841 & 0.173 & 1.518 & \\
\hline LEX & 0.142 & 0.093 & 0.652 & 28.471 & I (1) \\
\hline$\Delta$ LEX & -14.298 & -2.640 & 0.184 & 1.840 & \\
\hline LFDI & -0.365 & -0.207 & 0.566 & 20.950 & I (1) \\
\hline$\Delta$ LFDI & -16.359 & -2.857 & 0.174 & 1.508 & \\
\hline LRIR & -7.083 & -1.881 & 0.265 & 3.459 & I (1) \\
\hline$\Delta$ LRIR & -14.593 & -2.685 & 0.270 & 3.818 & \\
\hline
\end{tabular}

Source: Author's own Calculation by using E-views 8.0. $\Delta$ denotes the first difference of the series. $L$ implies that the variables have been transformed in natural logs.

Table 2: Lag Order Selection Criterion

\begin{tabular}{clccccc}
\hline Lag & LogL & LR & FPE & AIC & SIC & HQ \\
\hline 0 & -62.752 & NA & $1.01 \mathrm{e}-08$ & 4.288 & 4.650 & 4.410 \\
1 & 194.262 & $373.839^{*}$ & $9.36 \mathrm{e}-14^{*}$ & -7.409 & $-4.144^{*}$ & $-6.311^{*}$ \\
2 & 266.632 & 70.176 & $1.21 \mathrm{e}-13$ & $-7.917^{*}$ & -1.749 & -5.842 \\
\hline
\end{tabular}

* indicates lag order selected by the criterion

LR: sequential modified LR test statistic (each test at $5 \%$ level)

FPE: Final prediction error

AIC: Akaike information criterion

SC: Schwarz information criterion

$\mathrm{HQ}$ : Hannan-Quinn information criterion

After determining the order of integration of all the variables in table 1 , the next step is to employ an ARDL approach to co-integration in order to determine the long run relationship among the variables. By applying, the procedure in OLS regression for the first difference part of the equation (1) and then test for the joint significance of the parameters of the lagged level variables when added to the first regression. The FStatistics tests the joint Null hypothesis that the coefficients of lagged level variables in the equation (1) are zero. Table 3, reports the result of the calculated F-Statistics \& diagnostic tests of the estimated model. The result shows the calculated F-statistics are 5.5113. Thus the calculated F-statistics turns out to be higher than the upper- 
bound critical value at the 5 percent level. This suggests that there is a co-integrating relationship among the variables included in the model, i.e. Sensex (LBSE), Crude Oil Prices (LCO), Inflation (LCPI), Exchange Rate (LEX), Foreign Direct Investment (LFDI) and Real Interest Rate (LRIR).

\section{Table 3: ARDL Bounds test}

Panel I: Bound testing to co-integration:

Estimated Equation : $L B S E=F(L G D P, L C O, L C P I, L E X, L F D I, L R I R)$

\begin{tabular}{ll}
\hline Indicators & \\
\hline Optimal lag & 01 \\
F - Statistics & 5.5113 \\
\hline
\end{tabular}

Panel II: Diagnostic Tests:

\begin{tabular}{ll}
\hline Diagnostic Tests Indicators \\
\hline Normality J-B value & 0.8901 \\
Serial Correlation LM Test & 1.5214 \\
Heteroscedasticity Test (ARCH) & 1.0145 \\
Ramsey Reset Test & 0.0724 \\
\hline
\end{tabular}

The second step is to estimate the long- and short-run estimates of ARDL test. The long run results are illustrated in Table 4. King and Levine (1993) empirically estimated the Finance-Growth nexus, and concluded that the financial development are strongly associated with real per capita GDP growth. And the result of the present study shows the same, that the GDP and stock prices are strongly associated with a $1 \%$ level of significance. The empirical result shows that $1 \%$ in increase GDP lead to $2.311 \%$ increase in Stock Prices (Sensex). The findings are consistent with Fama $(1981,1990)$ and Chen et al. (1986) for GDP, that a rise in GDP has positive effect on stock prices.

The coefficient Inflation (LCPI), and Exchange Rate (LEX) are statistically significant and positive at $1 \%$. It is evident from the table that $1 \%$ in increase Inflation and Exchange Rate leads to $0.390 \%$ and $1.126 \%$, respectively, increase in Stock Prices (Sensex). The findings are consistent with Kessel (1956), loannidis et al. (2004) for Inflation; and Mukherjee and Naka (1995) and, Nadeem and Zakir (2009) for Exchange Rate.

Whereas, the coefficient of crude oil price is negative and significant the $1 \%$ level. Therefore, crude oil prices have a significant negative relationship adversely affecting stock prices, which may be due to the fact that the rising oil prices adversely affect earnings of those companies for which oil is a direct or indirect cost of production (Sadorsky, 1999; Maghyereh, 2004). If the firms cannot fully pass this cost increase to their consumers, the firm's profits and dividends, which are key drivers of stock prices will decline (Al-Fayoumi, 2009). The effect is immediate or lagged depending on the efficiency of the stock market. The findings of the present study are consistent with Miller and Ratti (2009), Le and Chang (2011); and Basher et al. (2012). 
Table 4: Estimated Long Run Coefficients using ARDL Approach (Dependent variable: LBSE)

\begin{tabular}{lccc}
\hline Regressors & \multicolumn{3}{c}{ ARDL(1,0,0,0) } \\
\cline { 2 - 4 } LGDP & Coefficient & t- values & Prob. Values \\
LCO & $2.311^{\star * *}$ & 4.047 & 0.000 \\
LCPI & $-0.917^{* * *}$ & -3.012 & 0.006 \\
LEX & $0.390^{* * *}$ & 2.060 & 0.050 \\
LFDI & $1.126^{* * *}$ & 3.372 & 0.002 \\
LRIR & -0.167 & -1.356 & 0.187 \\
CONS & 0.128 & 0.718 & 0.479 \\
Robustness Indicators & -4.202 & -2.936 & 0.007 \\
R $^{2}$ & & & \\
Adjusted R & 0.987 & & \\
F Statistics & 0.984 & & \\
D.W. Stat & $243.364[0.000]$ & & \\
Serial Correlation, F & 2.131 & & \\
Heteroskedasticity, F & $0.537 \quad[0.464]$ & & \\
Ramsey reset test, F & $0.424 \quad[0.515]$ & & \\
\hline
\end{tabular}

Note: (1) The lag order of the model is based on Schwarz Bayesian Criterion (SBC).

(2) ${ }^{* * *}$ indicate significant at the 1 percent level of significance. Values in [\#] are probability values.

The short-run relationship of the macroeconomic variables on stock market index is presented in Table 5. As can be seen from the table, GDP, Exchange Rate and Inflation have a significant and positive impact on stock market index in the short run also and similar to long-run is the situation for crude oil prices. The short run adjustment process is examined from the ECM coefficient. The coefficient lies between 0 and -1 , the equilibrium is converging to the long run equilibrium path, is responsive to any external shocks. However, if the value is positive, the equilibrium will be divergent from the reported values of ECM test. The coefficient of the lagged error-correction term $(-0.536)$ is significant at the $1 \%$ level of significance. The coefficient implies that a deviation from the equilibrium level of stock market index in the current period will be corrected by 53 percent in the next period to resort the equilibrium.

Table 5: Estimated Short Run Coefficients using ARDL Approach (Dependent variable: LBSE)

\begin{tabular}{lccc}
\hline Regressors & \multicolumn{3}{c}{ ARDL(1,0,0,0) } \\
\cline { 2 - 4 }$\Delta$ & Coefficient & T- Ratio & Prob. Values \\
$\Delta$ LGDP & $1.238^{* * *}$ & 4.006 & 0.000 \\
$\Delta$ LCPI & $-0.491^{* * *}$ & -3.277 & 0.003 \\
$\Delta$ LEX & $0.209^{*}$ & 1.749 & 0.092 \\
$\Delta$ LFDI & $0.604^{* *}$ & 2.183 & 0.038 \\
$\Delta$ LRIR & 0.049 & 0.804 & 0.429 \\
$\Delta$ CONS & 0.069 & 0.719 & 0.478 \\
ECM t-1 & -2.251 & -2.056 & 0.050 \\
Robustness Indicators & -0.536 & -3.333 & 0.003 \\
\hline
\end{tabular}




\begin{tabular}{ll}
\hline$R^{2}$ & 0.459 \\
Adjusted R2 & 0.286 \\
D.W. Stat & 2.131 \\
SE Regression & 0.195 \\
RSS & 0.952 \\
F Statistics & $3.029[0.018]$ \\
\hline
\end{tabular}

Note: (1) The lag order of the model is based on Schwarz Bayesian Criterion (SBC).

(2) ${ }^{*},{ }^{* *}$ and ${ }^{* * *}$ indicate significant at 10,5 and 1 percent level of significance, respectively. Values in [\#] are probability values.

The next step is to test for the causality between the variables, the short run and long run granger causality test findings are reported in Table 6 . The results of table 6 indicate that short run unidirectional causality running from LFDI, LGDP and LRIR to LBSE in India. In context to LGDP and stock market development, the results are differing to Levine and Zervos (1998). It is also observed that error correction term is statistically significant for specification with LBSE as the dependent variable which indicate that there exist a long run causal relationship among the variable with LBSE as the dependent variable. This result is also confirmed by the ARDL test statistics.

Table 6: Results of Vector Error Correction Model

\begin{tabular}{|c|c|c|c|c|c|c|c|c|}
\hline \multirow{3}{*}{$\begin{array}{r}\text { Depend } \\
\text { ent } \\
\text { variable }\end{array}$} & & & & & & & \multicolumn{2}{|c|}{ Sources of Causation } \\
\hline & & & & & \multicolumn{3}{|c|}{ Short run independent variables } & Long run \\
\hline & LBSE & LCO & LCPI & LEX & LFDI & LGDP & LRIR & $E C M_{(t-1)}$ \\
\hline LBSE & - & 0.636 & -1.283 & -1.414 & $3.115^{\star * *}$ & $-2.239^{* *}$ & $1.916^{*}$ & $-3.906^{* * *}$ \\
\hline LCO & 0.198 & - & 0.174 & -0.293 & -0.407 & 0.389 & -0.378 & -0.849 \\
\hline LCPI & 0.183 & -1.157 & - & $-1.757^{*}$ & 0.911 & 0.823 & 0.135 & 0.691 \\
\hline LEX & 0.544 & 0.086 & 0.292 & - & -1.044 & 0.089 & 0.722 & -0.402 \\
\hline LFDI & 1.590 & $1.792^{*}$ & -0.416 & -0.056 & - & -0.396 & -0.306 & -0.149 \\
\hline LGDP & 0.433 & 0.433 & -0.920 & -1.651 & 1.632 & - & -0.379 & -1.230 \\
\hline LRIR & -0.284 & 0.484 & -0.579 & 0.694 & 0.655 & 0.242 & - & -1.066 \\
\hline
\end{tabular}

The robustness of the short run result are investigated with the help of diagnostic and stability tests. The ARDL-VECM model passes the diagnostic against serial correlation, functional misspecification and non-normal error. The cumulative sum (CUSUM) and the cumulative sum of square (CUSUMSQ) tests have been employed in the present study to investigate the stability of a long run and short run parameters. The cumulative sum (CUSUM) and the cumulative sum of square (CUSUMSQ) plots (Figure 1) are between critical boundaries at $5 \%$ level of significance. This confirms the stability property of a long run and short run parameters which have an impact on the market index in case of India. This confirms that models seem to be steady and specified appropriately. 
Figure 1:

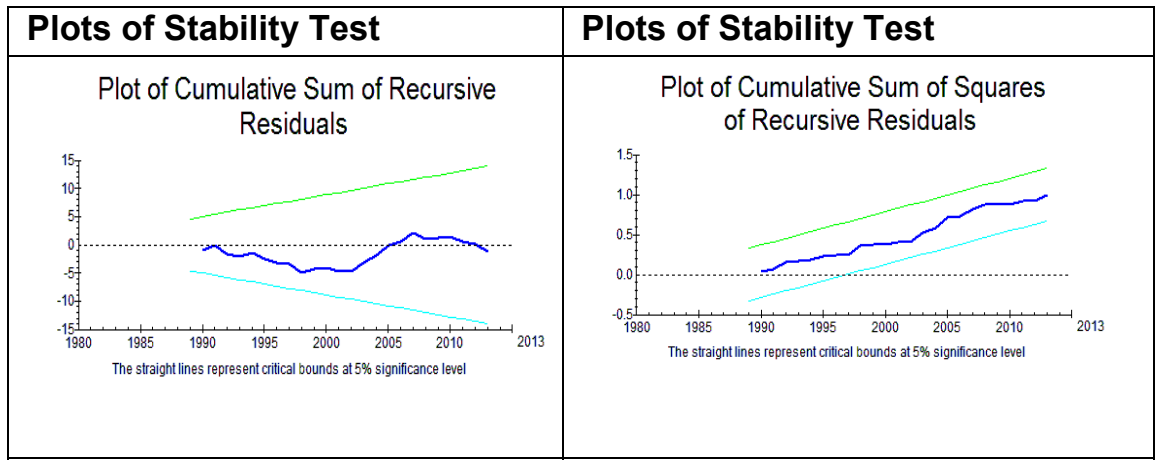

\section{Variance Decomposition (VDC) Analysis:}

It is pointed out by Pesaran and Shin (2001) that the variable decomposition method shows the contribution in one variable due to innovation shocks stemming in the forcing variables. The variance decomposition indicates the amount of information each variable contributes to the other variables in the autoregression. It determines how much of the forecast error variance of each of the variables can be explained by exogenous shocks to the other variables. The main advantage of this approach as it is insensitive to the ordering of the variables. The results of the VDC are presented in table 7. The empirical evidence indicates that $78.33 \%$ of stock price change is contributed by its own innovative shocks. Further, shock in crude oil price explains the stock price by $12.73 \%$. Foreign Direct Investment contributes to stock prices by $2.835 \%$ and consumer price contributes $2.01 \%$. From this analysis, it can be referred that the movement in stock prices can be predicted from the crude oil prices. The share of other variables is very minimal.

Table 7: Variance Decomposition (VDC) Analysis

\begin{tabular}{rrrrrrrrr}
\hline $\begin{array}{r}\text { Per } \\
\text { iod }\end{array}$ & S.E. & LBSE & LCO & LCPI & LEX & LFDI & LGDP & LRIR \\
\hline 1 & 0.223 & 100.00 & 0.000 & 0.000 & 0.000 & 0.000 & 0.000 & 0.000 \\
& & 0 & & & & & & \\
2 & 0.303 & 91.256 & 2.442 & 2.718 & 0.151 & 2.108 & 0.814 & 0.065 \\
3 & 0.344 & 88.673 & 4.758 & 2.145 & 0.367 & 2.499 & 0.717 & 0.183 \\
4 & 0.366 & 86.802 & 6.364 & 1.962 & 0.397 & 2.624 & 0.651 & 0.365 \\
5 & 0.379 & 85.334 & 7.528 & 1.916 & 0.372 & 2.720 & 0.609 & 0.541 \\
6 & 0.386 & 84.115 & 8.473 & 1.864 & 0.384 & 2.803 & 0.596 & 0.678 \\
7 & 0.391 & 83.047 & 9.289 & 1.816 & 0.442 & 2.861 & 0.621 & 0.765 \\
8 & 0.395 & 82.091 & 10.001 & 1.802 & 0.524 & 2.889 & 0.652 & 0.809 \\
9 & 0.398 & 81.242 & 10.613 & 1.827 & 0.604 & 2.895 & 0.758 & 0.827 \\
10 & 0.401 & 80.510 & 11.131 & 1.875 & 0.671 & 2.888 & 0.833 & 0.830 \\
11 & 0.404 & 79.897 & 11.568 & 1.926 & 0.720 & 2.876 & 0.895 & 0.828 \\
12 & 0.406 & 79.393 & 11.935 & 1.968 & 0.755 & 2.863 & 0.941 & 0.824 \\
13 & 0.409 & 78.978 & 12.245 & 1.995 & 0.777 & 2.852 & 0.974 & 0.820 \\
14 & 0.411 & 78.632 & 12.510 & 2.010 & 0.792 & 2.842 & 0.997 & 0.817 \\
15 & 0.413 & 78.337 & 12.737 & 2.014 & 0.800 & 2.835 & 1.013 & 0.816 \\
\hline \multicolumn{7}{c}{ Cholesky Ordering: LBSE LCO LCPI LEX LFDI LGDP LRIR } \\
\hline
\end{tabular}




\section{Conclusions and Policy Implications}

An effort has been made in this paper to investigate whether fundamental macroeconomic variables affect the stock price in India or not. Towards this effort, we have used annual data from 1979 to 2014 for the all the variables included in the estimation. The present paper used ARDL bounds testing approach to study the longrun co-integrating relationship among the variables. The bounds test confirms that there exist a long-run co-integration relationship between different macroeconomic variables and stock prices in India. The long-run estimates of ARDL test showed that positive and significant relationship exists between economic growth and stock prices. It also confirms a significant and positive influence of Exchange Rate and Inflation on stock price movements in India. However, there exists a negative and significant relationship between crude oil price and stock prices.

The error correction model of ARDL approach reveals that the adjustment process from the short-run deviation is quite high. More precisely, it is found that the $\mathrm{ECM}_{\mathrm{t}-1}$ term is -0.536 . This term is significant at $1 \%$, again confirming the existence of co-integration that the derivation from the long run equilibrium path is corrected $53 \%$ per year. To determine the direction of causality VECM is used in the study and the result shows that there exists a short run unidirectional causality running from foreign direct investment, GDP and real interest rate to BSE in India. In contrast to the studies of King and Levine (1993) and Levine and Zervos (1998), both the ARDL and the VECM results of this paper seem to indicate that GDP growth causes stock price growth.

Further, the result indicates the presence of long run causality for the equation with the stock price as the dependent variable. The CUSUM and CUSUMSQ test results suggest the policy changes considering the explanatory variables of the stock price equation will not cause major distortions in India. To predict the long-run and short-run shocks variance decomposition is used for the study, the results of the VDC analysis show that a major percentage of stock price change is its own innovative shocks.

The finding implies that, in a country when the real GDP will raise it will help stock prices to increase and boost up the investor's confidence, with the growing economy. GDP is the most crucial economic indicator which tells us about the health of our economy. It can help companies and investors decide on what strategies they should adopt as also indicate to the policy makers, the effectiveness of the steps and decisions they have undertaken. Higher economic activity implies higher expected profitability, which causes stock prices to rise. Further, in a country when the crude oil prices will raise it will lead stock prices to decrease. But up to some extent that the negative impact of oil prices can be mitigated, only if the uses of alternative energy resources are facilitated. Additionally, it is also suggested that the stock market returns may provide an effective hedge against inflation in India. This is explained by the 
significant and positive relationship between inflation and stock prices as the Fisher (1930) hypothesis postulates. This also implies that investors in making better portfolio decisions should perhaps view, shares as long-term holdings against inflation's loss of purchasing power.

The relationship between real exchange rates and stock prices may be useful for portfolio managers interested in global asset allocation or investors trying to hedge against foreign exchange risk. The results have implications for domestic as well as foreign investors, stock market regulators, policy makers and stock market analysts. Investors and stock market analysts could forecast stock prices and earn profits. Stock market regulators could take initiatives for the accountability of companies to prevent manipulation of stock prices and to educate layman investors for stock market and encourage them to invest in stocks. Policy makers should be acquainted of these macroeconomic effects on stock market and help them to take efficient and effective decisions.

\section{References}

Abugri, B. A. (2008). Empirical Relationship between Macroeconomic Volatility and Stock Return: Evidence from Latin American Markets. International Review of Financial Analysis, Vol. 17(2), pp. 396-410.

Adam, Anokye M. and Tweneboah, George (2008). Macroeconomic Factors and Stock Market Movement: Evidence from Ghana. Unpublished. Available at http://mpra.ub.uni-muenchen.de/11256/.

Agrawalla (2008). Share Prices and Macroeconomic Variables in India: An Approach to Investigate the Relationship between Stock Markets and Economic Growth. IGIDR Money \& Finance Conference.

Alam, M. M., \& Uddin, M. G. S. (2009). Relationship between interest rate and stock price: empirical evidence from developed and developing countries. International journal of business and management, Vol. 4(3), pp. 43-51.

Basher, S. A., Haug, A. A. and Sadorsky, P. (2012). Oil prices, exchange rates and emerging stock markets. Energy Economics, Vol. 34(1) pp. 227-240.

Beck, T. and Levine, R. (2004). Stock Markets, Banks, and Growth: Panel Evidence. Journal of Banking and Finance, Vol. 28(3), pp. 423-442.

Bekhet, H. A. and Matar, A. (2013). Co-integration and causality analysis between stock market prices and their determinants in Jordan. Economic Modelling, Vol. 35, pp. 508-514.

Ben Naceur, S., Ghazouani, S., and Omrani, M. (2007). The determinants of stock market development in the Middle-Eastern and North African region. Managerial Finance, Vol. 33(7), pp. 477-489

Bhargava, A. (2014). Firms' fundamentals, macroeconomic variables and quarterly stock prices in the US, Journal of Econometrics. 183(2), pp. 241-250

Charles Amo Yartey (2008). The Determinants of Stock Market Development in Emerging Economies: Is South Africa Different?. IMF Working Paper African Department, Working, WP/08/32

Chen, N. F., Roll, R. and Ross, S.A. (1986). Economic forces and the stock market. Journal of Business, Vol. 59(3), pp. 383-403. 
Cheng, Y. W. and Ng, L. K. (1998). International evidence on the stock market and aggregate economic activity. Journal of Empirical Finance, Vol. 5 (3, pp. 281-296.

Coleman, A. K. and Tettey, K. F. A. (2008). Impact of macroeconomic indicators on stock market performance. Journal of Risk Finance, Vol. 9(4), pp. 365-78.

Engle, R. F., \& Granger, C. W. (1987). Co-integration and error-correction: Representation, estimation and testing. Econometrica, Vol. 55(2), pp. 251-276.

Fama, E. F. (1990). Stock returns, expected returns, and real activity. The Journal of Finance, Vol. 45(4), pp. 1089-1108.

Fama, E. F. (1991). Efficient capital markets: II. The Journal of Finance, Vol. 46(5), pp. 1575-1617.

Fama, E., (1981). Stock returns, real activity, inflation and money. American Economic Review, Vol. 71, pp. 545-565.

Flannery, M. J. and Protopapadakis, R. H. (2002). Macroeconomic factors do influence aggregate stock returns. Review of Financial Studies, Vol. 15(3), pp. 751-782.

Gay-Jr, R.D. (2008). Effect of Macroeconomic Variables on Stock Returns for Four Emerging Economics: Brazil, Russia, India and China. International Business \& Economics Research Journal, Vol. 7(3), pp. 1-8.

Gjrde, $\varnothing$. and Saetten, F. (1999). Causal relation among stock returns and macroeconomic variables in a small, open economy. Journal of International Financial Markets, Institutions and Money, Vol. 9(1), pp. 61-74.

Hsing, Y. (2004). Impacts of Fiscal Policy, Monetary Policy, and Exchange Rate Policy on Real GDP in Brazil: A VAR Model. Brazilian Electronic Journal of Economics, Vol. 6(1), pp. 1-12.

Hussin, M., Yahya, M., Muhammad, F., \& Awang, S. A. (2012). Macroeconomic variables and Malaysian Islamic stock market: a time series analysis. The Journal of Business Studies Quarterly, Vol. 3(4), pp. 1-13.

Ibrahim, M.H. and Aziz, H. (2003). Macroeconomic variables and the Malaysian equity market: A View Theory Rolling Subsample. Journal of Economic Studies, Vol. 30(1), pp. 6-27.

Ioannidis, D., Katrakilidis, K., \& Lake, A. E. (2004). Inflation, Uncertainty and Stock Market Returns Evidence Using Greek Data. NBER working paper.

Jones, C. M., \& Kaul, G. (1996). Oil and the stock markets. The journal of Finance, Vol. 51(2), pp. 463-491.

Kanakaraj, A., Singh, B. K. and Alex, D. (2008). Stock Prices, Micro Reasons and Macro Economy in India: What do data say between 1997-2007. Fox Working Paper 3, pp. 1-17.

Kessel, R. A. (1956). Inflation-caused wealth redistribution: A test of a hypothesis. The American Economic Review, Vol 46(1), pp. 128-141.

Kim, S. J., McKenzie, M., Faff, R. (2004). Macroeconomic news announcements and the role of expectations: evidence for US bond, stock and foreign exchange markets. Journal of Multinational Financial Management, Vol. 14(3), pp. 217-232.

King, R.G. and Levine, R. (1993). Finance and Growth: Schumpeter Might Be Right. Quarterly Journal of Economics, Vol. 108(3), pp. 717-738.

Le, N.P. and Chang, Y. (2012). The impact of oil price fluctuations on stock markets in developed and emerging economies. MPRA Paper No. 31753.

Levine, R. (1991). Stock markets, growth, and tax policy. Journal of Finance, Vol. 46(4), pp. 1445-1465. 
Levine, R. (2005). Finance and Growth: Theory and Evidence, in: P. Aghion and S.N. Durlauf (eds.), Handbook of Economic Growth, Elsevier, Amsterdam, pp. 865-934.

Levine, R., Loayza, N. and Beck, T. (2000). Finance and the Sources of Growth. Journal of Financial Economics, Vol. 58(1), pp. 261-300.

Levine, R., \& Zervos, S. (1996). Stock market development and long-run growth. World Bank Economic Review, Vol. 10(2), pp. 323-339.

Levine, R. and Zervos, S. (1998). Stock Markets, Banks, and Economic Growth. American Economic Review, Vol. 88(3), pp. 537-558.

Lijuan, W., \& Ye, X. (2010). Empirical Analysis of Macroeconomic Factors Affecting the Stock Price. Orient Academic Forum.

Makan, C., Ahuja, A.K. and Chauhan, S. (2012), "A Study of the Effect of Macroeconomic Variables on Stock Market: Indian Perspective”, MPRA Paper No. 43313

Maysami et al. (2004). Relationship between Macroeconomic Variables and Stock Market Indices: Cointegration Evidence from Stock Exchange of Singapore's All-S Sector Indices. Jurnal Pengurusan, Vol. 24(1), pp. 47-77.

Mazuruse, P. (2014). Canonical correlation analysis: Macroeconomic variables versus stock returns. Journal of Financial Economic Policy, Vol. 6(2), pp. 179-196.

Miller, J. I., \& Ratti, R. A. (2009). Crude oil and stock markets: Stability, instability, and bubbles. Energy Economics, Vol. 31(4), pp. 559-568.

Mokerjee, R. and Qiao, Y. (1997). Macroeconomic variables and stock prices in a small open economy: the case of Singapore. Pacific - Basin Finance Journal, Vol. 5(3), pp. 377-388.

Mukherjee and Naka (1995). Dynamic relations between macroeconomic variables and the Japanese stock market: An application of a vector error correction model. Journal of Financial Research, Vol. 18(2), pp. 223-237.

Naik, P. K., and Padhi, P. (2012). The Impact of Macroeconomic Fundamentals on Stock Prices Revisited: Evidence from Indian Data. Eurasian Journal of Business and Economics, Vol. 5(10), pp. 25-44.

Nishat, M. And Shaheen, R. (2004). Macroeconomic Factors and Pakistani Equity Market. The Pakistan Development Review, Vol. 43(4), pp. 619-637.

Pal, K., \& Mittal, R. (2011). Impact of macroeconomic indicators on Indian capital markets. Journal of Risk Finance, Vol. 12(2), pp. 84-97.

Pearce, D. K., \& Roley, V. V. (1988). Firm characteristics, unanticipated inflation, and stock returns. The Journal of Finance, Vol. 43(4), pp. 965-981.

Pesaran, M.H., Shin, Y., Smith, R.J. (2001). Bounds testing approaches to the analysis of level relationships. Journal of Applied Economics, Vol. 16(3), pp. 289-326.

Poon, S. H. and Taylor, S. J. (1992). Stock returns and volatility: an empirical study of the UK stock market. Journal of Banking and Finance, Vol. 16(1), pp. 37-59.

Pradhan, R. P., et al. (2014). Causal nexus between economic growth, banking sector development, stock market development, and other macroeconomic variables. The Review of Financial Economics. http://dx.doi.org/10.1016/j.rfe.2014.07.002

Rafay, A., Naz, F., \& Rubab, S. (2014). Causal Relationship between Macroeconomic Variables: Evidence from Developing Economy. Journal of Contemporary Issues in Business Research, Vol. 3(2), pp. 88-99.

Rahman et al. (2009). Macroeconomic Determinants of Malaysian Stock Market. African Journal of Business Management. Vol. 3(3), pp. 95-106. 
Ratanapakorn, O. and Sharma, S. C. (2007). Dynamics analysis between the US Stock Return and the Macroeconomics Variables. Applied Financial Economics, Vol. 17(4), pp. 369-377.

Ray, D. S. (2012). Testing Granger Causal Relationship between Macroeconomic Variables and Stock Price Behaviour: Evidence from India. Advances in Applied Economics and Finance, Vol. 3(1), pp. 470-481.

Raza, A., Iqbal, N., Ahmed, Z., Ahmed, M., \& Ahmed, T. (2012). The role of FDI on stock market development: the case of Pakistan. Journal of Economics and Behavioral Studies, Vol. 4(1), pp. 26-33.

Raza, S. A., \& Jawaid, S. T. (2014). Foreign capital inflows, economic growth and stock market capitalization in Asian countries: an ARDL bound testing approach. Quality \& Quantity, Vol. 48(1), pp. 375-385.

Sahay, R., Cihak, M., N'Diaye, P., Barajas, A., Bi, R., Ayala, D., Gao, Y., Kyobe, A., Nguyen, L., Saborowski, C., Svirydzenka, K., and Yousefi, S.R. (2015). Rethinking Financial Deepening: Stability and Growth in Emerging Markets. IMF Staff Discussion Note 15/08, International Monetary Fund, Washington, D.C.

Sahu, T. N., Bandopadhyay, K., \& Mondal, D. (2014). An empirical study on the dynamic relationship between oil prices and Indian stock market. Managerial Finance, Vol. 40(2), pp. 200-215.

Shah A, Thomas S (1997). Securities Markets. In KS Parikh (ed.), "India Development Report 1997, Oxford University Press", chapter 10, pp. 167-192.

Sharma et. Al. (2002). A Structural VAR Model of the New Zealand Business Cycle. Wellington: The Treasury.

Sohail, N., \& Hussain, Z. (2009). Long-Run and Short-Run Relationship between Macroeconomic Variables and Stock Prices in Pakistan: The Case of Lahore Stock Exchange. Pakistan Economic and Social Review, Vol. 47(2), pp. 183-198.

Uddin, M. G. S. and Alam, M. M. (2007). The Impacts of Interest Rate on Stock Market: Empirical Evidence from Dhaka Stock Exchange. South Asian Journal of Management and Sciences, Vol. 1(2), pp. 123-132.

Yu Hsing, Michael C. Budden (2012). Macroeconomic Determinants of the Stock Market Index for a Major Latin American Country and Policy Implications. Business and Economic Research, Vol. 2(1). 